\title{
Arabic Vocabulary Acquisition through Short Animation Movie
}

\author{
$1^{\text {st }}$ Nafisatul Fuadah ${ }^{1}, 2^{\text {nd }}$ Miftakhul Fariz ${ }^{1}, 3^{\text {rd }}$ Rohmani Nur Indah ${ }^{1}$ \\ \{navischute@gmail.com¹, miftakhulfariz@gmail.com ${ }^{1}$, indah@bsi.uin-malang.ac.id ${ }^{1}$ \} \\ Universitas Islam Negeri Maulana Malik Ibrahim, Malang, Indonesia ${ }^{1}$
}

\begin{abstract}
Vocabulary is one of the core components of a language. Its mastery is very significant to enable one's interaction and communication within the community so that the messages conveyed can be channeled properly and the communication can be effective. Therefore, the vocabulary has always been an interesting study to learn, without exception in Arabic. This paper explores how vocabulary can be obtained through cartoons. Cartoon is a form of entertainment product attractive for various circles, including children, teenagers or adults for its fun content. Beginners of Arabic learn can acquire Arabic vocabulary naturally through cartoon. Current researches deal with the effectiveness of cartoon movies in foreign language classroom. However, how cartoon movies in short duration can affect one's vocabulary acquisition still needs more exploration. The method used in this study is qualitative descriptive with data collection technique of observation and interview. The, results show that cartoons can be an effective bridge between novelty of the vocabulary and learner's acquisition for beginners who never had a history of previous Arabic learning. As the implication, the use of cartoon as audiovisual language stimuli is recommended for Arabic language acquisition particularly of those from elementary level.
\end{abstract}

Keywords: Arabic for beginners; short animation movie; vocabulary acquisition

\section{Introduction}

Language acquisition is an important part of psycholinguistic discourse in the form of speech, vocabulary, and in the form of sentences in a good and perfect way. As with other languages, Arabic also has several hierarchical language skills and components. Starting from listening skills (maharah istima'), speaking (maharah kalam), reading (maharah qira'ah) and writing (maharah kitabah). The importance of mastering the four skills then does not shift the urgency of mastering the language component which consists of utterance (aswat), language structure (qawaid) and vocabulary (mufrodat).

This study focuses on acquiring language vocabulary. Vocabulary is as a list of words that have meaning in a language [1]. Thus vocabulary is the main foundation for speakers to be able to communicate orally or in writing. This is in line with the statement that speakers of good language are those who have sufficient vocabulary wealth, so as to be able to communicate with native speakers of the language well [2]. With the vocabulary treasury that is owned, one can express the message to be conveyed. 
Vocabulary is the parent of a language. The theory of vocabulary acquisition requires a complex understanding of how language is acquired. Language acquisition is the process by which a person acquires the ability to understand and use vocabulary in everyday interactions and communication.

Language acquisition is proposed by Krashen as a product of a process that occurs naturally as a child processes to obtain his first language [3]. In line with this understanding, language acquisition turns out to be a process that takes place in a child's brain when the first language is acquired [4].

Vocabulary is a set of several words that will form language [5]. The wealth of words owned by a person or several words used by a particular field is also called vocabulary. Besides that vocabulary also refers to a list of words in a dictionary accompanied by a brief and practical explanation [6]. In general, rich vocabulary is considered as an illustration of one's intelligence. This was confirmed that the quantity of vocabulary a person has reflects the quality of his language [7]. The use of vocabulary arranged in sentences is able to represent various events and experiences in one's life. Therefore, vocabulary has always been an interesting study to learn, not least in Arabic.

Understanding of first language acquisition and second language has little difference. Generally, the first language is acquired unconsciously during childhood supported by the interaction with parents and the environment. While the second language is obtained through learning, both from formal learning held in the classroom and informal learning that can be carried out wherever with the presence of educators and learners, as well as the material taught. This statement is supported by the opinion which states that language acquisition is related to the first language, while language learning is related to the second language [4].

However, in the process, the way of obtaining a second language - in this case, Arabic can be broken down into two, namely the acquisition of a second language consciously and second language acquisition naturally or naturally. This opinion refers to Krashen and Terrell. The concept is similar to the two models described by Ellis, namely: (1) The acquisition of a second language naturalistic type (natural) without a teacher, and without intention. (2) The acquisition of the second language of the formal type (guided) is carefully prepared, in the form of material, tools, classes and professional teachers [4]. Based on the two types mentioned, the acquisition of Arabic vocabulary through cartoon films is included in the category of natural language acquisition, not designed and also not planned

In this global era, there are various ways to obtain language vocabulary, one of them is through cartoon media. Cartoon film is a manifestation of the results of technological developments that are in demand by various groups, either children, adolescents or adults. The use of cartoon films has the opportunity to create a pleasant atmosphere for Arabic language acquisition. For beginners, it is certainly very influential because in most application of Arabic language learning, they are forced to memorize new vocabulary. If this method continues to be applied, it is feared that there will be gaps and boredom. However, cartoon films will foster the spirit of beginner learners in obtaining Arabic vocabulary.

Cartoons are one of the learning media that tend not to be monotonous and not boring because of language stimuli that are presented in the form of audio visuals and in film formats that have a storyline. Not only this, by utilizing cartoon films, one not only obtains vocabulary but can also listen to speech directly from native speakers, so they can pronounce the pronunciation correctly. Students can explore conversations between characters in cartoon films and can observe all forms of linguistic stimuli such as intonation, dialect, and gestures, making it easier for them to remember the vocabulary obtained. This information is certainly 
the best target for the linguistic world so that in the future it can develop theories of language acquisition, especially Arabic.

Until now, it is still relatively few who explored studies about acquiring Arabic vocabulary, especially for beginners using cartoon media. A description of the Arabic vocabulary acquisition model from cartoon film media for beginners is needed, in the form of verbs, nouns, even simple sentences such as greetings and thanksgiving. This is the basis for the selection of the theme of this study, namely the acquisition of Arabic vocabulary through cartoon films. The implication of this study is to be an answer for beginners who want to obtain Arabic vocabulary contextually, so as to create a pleasant atmosphere and the acquisition of language vocabulary can take place effectively.

\section{Literature Review}

\subsection{Animation Movie}

Judging from its history, movie or the film that appeared the first time was a film created by Lumiere Brothers in 1850. It was not until 1899 that a film appeared that had the style of an editing by George Melies entitled "Trip to the Moon" [8]. The film comes without sound effects or is called silent film. A sound film began in America [9]. Film is a communication medium that can convey reality in everyday life and can tell a society in a particular area and at a certain time. The film as a collection of several images strung together in such a way is called 'moving picture'. Furthermore, films are categorized into several groups, namely films with story genres, documentary films, glass screen films and cartoon films [10].

Animation movie or cartoon films are also called animations which present a collection of several images that can move quickly so that the image is like having a soul and looks alive [11]. Cartoon films are included in the category of audio visual media, which can give two positive things. First, viewers who are aged students do not depend on the time of transmission, but they can watch videos freely if they feel possible; for example, they can choose to watch videos based on their preference. Second, with video media, one can control the program being watched by stopping and advancing or rewind the show according to what is desired [12]. Cartoon films can also be defined as the media used by someone to present more tangible objects. One of the benefits of cartoon films is that it can pack information and experiences in an interesting form [13].

\subsection{Acquistion of Foreign Language Vocabulary}

In a study modeled on a case study observing how students in South Konawe, the children get Arabic vocabulary at school from 2-7 years old. The instructors at the school still showed a lot of errors in pronunciation, so that the vocabulary received by the students was not optimal and it could be a fatal mistake for students to obtain Arabic vocabulary. Because of inadequate language acquisition with the right examples, students when reading are still heard mixing their mother tongue with the Arabic they learned through the teacher [14].

Other studies raised the acquisition of English through cartoon films. This study observes a child named Fiola who is five years old by using the cartoon film "Dora The Explorer" as an English vocabulary learning media for preschoolers. From the results of observations for six months, the vocabulary obtained is in the form of a single word, such as: play, go, jump, and others. After a few months, the vocabulary developed into a phrase like jump up please! The results of this study indicate that learning incidental English vocabulary through this cartoon is 
effective for preschool children [15]. In addition, cartoon film media will minimize the emergence of errors in vocabulary pronunciation because in the film full of phonological exposures delivered in context [16].

In animated movies, in addition to audiovisual language stimuli, students are helped to connect the form of language and the sound of language with subtitles [17]. That's why it also supports student's pronunciation to adjust with phonetic production according to the target language [18]. Through audiovisual stimuli in film, students can increase the number of English vocabulary acquisition significantly as applied to student groups in Turkey [19].

However, studies that collaborate between acquiring Arabic and using cartoons are still not widely explored. So far the cartoon film has been studied in the context of English learning in class. The use of cartoon filings in acquiring Arabic outside the context of teaching still requires an empirical foundation. For this reason, this study is done to identify whether cartoons in Arabic also have the same impact as other foreign languages.

\section{Methods}

This study uses a qualitative method. In this method the data is produced in the form of descriptive, in the form of writing, speech or behavior from the person who is used as the object of observation [20]. In this study the goal is to understand the objects and social context naturally so that the information and data obtained are valid and accurate regarding the acquisition of Arabic vocabulary through cartoon films. Furthermore, qualitative research has natural and human background characteristics as instruments. The data analysis process is carried out inductively. For this reason, special criteria are needed to obtain data validity [20]. As for in this study the criteria of the subjects observed were non-Arabic speakers who had never studied Arabic before. This is to see the extent to which cartoon films can influence the acquisition of vocabulary in research subjects.

Participants in this study involved Indonesian speakers who had never studied Arabic, aged 17-22 years, students or students. Female subjects were repre- sented by ANS and AY, while male subjects were represented by AN and RZ.

Research with qualitative methods examines the condition of objects naturally [21]. For this reason, in the data collection process cartoon films are used which can be seen by research subjects without interference from researchers. The cartoon film shown is only four minutes long, with clear pronunciation and vocabulary commonly used in everyday life. This is done so that participants can easily remember the vocabulary obtained which can then be applied in their learning activities. In addition, participants are also free to play cartoons, whether to advance, rewind, repeat, or stop certain parts. This treatment is applied so that participants get a good impression and a pleasant atmosphere in acquiring Arabic vocabulary for the first time so that they can foster their enthusiasm to learn more intense Arabic.

Here, the researchers are also as key instrument. To get the desired data, observation and interview techniques are used. Observation is chosen so that researchers can observe the object of research directly to obtain factual and accurate information. Observation is a way of obtaining the information needed based on what is seen and what is heard [22]. In this study, observations were used to observe participants in the form of circumstances, behavior, facial expressions when they watched cartoons. While the interview is a data collection technique in the form of question and answer between researchers and informants to obtain information orally. Applicatively, interviews were conducted to find out what vocabulary was obtained 
from the cartoon films that had been aired and asked participants' feelings while watching cartoons.

The research steps applied by researchers include: (1) finding and choosing interesting Arabic language cartoons with clear pronunciation, and the right tempo for beginners and vocabulary that is close to daily life; (2) giving participants the freedom to watch cartoons with the frequency they want, whether they are repeatedly playing, advancing, rewinding or stopping them in certain parts; (3) observing participants during cartoon watching activities; (4) after completion, the researcher asks what vocabulary can be understood by participants from the cartoon that has been watched; (5) analyzing data by classifying words obtained by word type and answering research questions; and (6) making conclusions

\section{Result \& Discussion}

From the observations, the vocabulary mastered by the participants is based on the type of words or phrases they get after watching cartoons, namely verbs, adjective, nouns and simple phrases.

Table 1. Mapping Verb Acquisition

\begin{tabular}{|c|c|c|c|}
\hline No. & Name & $\begin{array}{l}\text { Verbs } \\
\text { كلمة فعل }\end{array}$ & Sum \\
\hline 1. & ANS & 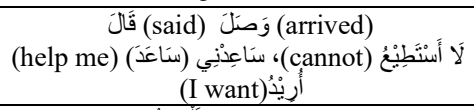 & 5 \\
\hline 2. & AY & $\begin{array}{c}\text { ألحَمْدُ (appraise) } \\
\text { (said) قَالَ) }\end{array}$ & 2 \\
\hline 3. & AN & 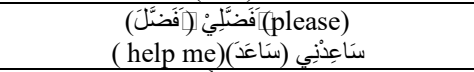 & 2 \\
\hline 4. & $\mathrm{RZ}$ & 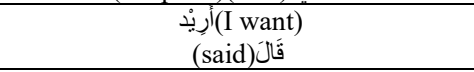 & 2 \\
\hline
\end{tabular}

A verb is an easier acquisition especially with the support of a moving picture that explains the purpose of the verb in question. In table 1 , the number of verbs is obtained from at least two words including قال (say) and words consisting of two to three syllables. Verbs obtained include words that are often spoken by characters in a cartoon film seen by participants. Verbs are predicates in sentences that often appear at the beginning of speech so that participants are easily captured. Verbs that are often heard also make it easier to acquire, for example لحمد (I praise).

Table 2. Mapping Adjective Acquisition

\begin{tabular}{|c|c|c|c|}
\hline No. & Name & نعت Adjectives & Sum \\
\hline 1. & ANS & 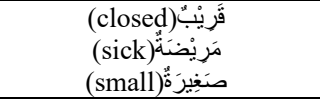 & 3 \\
\hline 2. & AY & صَبرَ (patient) & 1 \\
\hline 3. & $\mathrm{AN}$ & -- & 0 \\
\hline 4. & RZ & أُوَّلُ (first) صَالِحَةٌُ (sholihah) & 2 \\
\hline
\end{tabular}


The acquisition of adjectives is less than the verb because participants try to understand the explanatory word of the subject through a visual context presented in a cartoon. Even one participant did not show an acquisition. Among the adjectives obtained include absorption loan words such as patience (sabr), sholihah and first (awwal).

Table 3. Mapping Noun Acquisition

\begin{tabular}{|c|c|c|c|}
\hline No. & Name & Souns & Sum \\
\hline 1. & ANS & 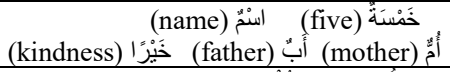 & 5 \\
\hline 2. & AY & 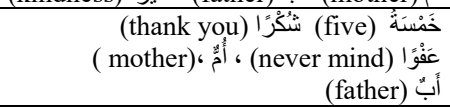 & 5 \\
\hline 3. & AN & 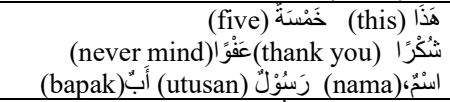 & 7 \\
\hline 4. & $\mathrm{RZ}$ & 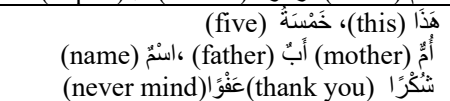 & 7 \\
\hline
\end{tabular}

The acquisition of nouns is more than verbs and adjectives because the understanding of participants is helped by the visual context presented in cartoons. Among the adjectives obtained include common words such as apostles, abi, umi, syukron, and afwan. Numerical words that are very familiar to participants, namely خمسة (five). In addition to the above nouns, one of the participants (ANS) also called the conjunction لكن (but).

Table 4. Mapping Acquisition on Simple Phrases

\begin{tabular}{|c|c|c|c|}
\hline No. & Name & Phrases & Sum \\
\hline 1. & ANS & 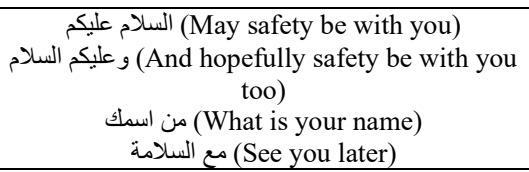 & 5 \\
\hline 2. & $\mathrm{AY}$ & 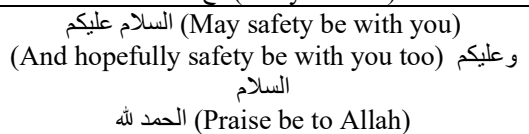 & 5 \\
\hline 3. & $\mathrm{AN}$ & 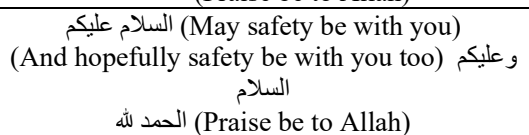 & 7 \\
\hline 4. & $\mathrm{RZ}$ & $\begin{array}{c}\text { و عليكم (May safety be with you) } \\
\text { (And hopefully safety be with you too) السلام عليكم السلام (Praise be to Allah) } \\
\text { الحمد لله }\end{array}$ & 7 \\
\hline
\end{tabular}

The acquisition of simple phrases is supported by the understanding of participants in the visual context presented in cartoons and includes phrases commonly heard. All participants are very familiar with greetings. In addition to obtaining vocabulary in the form of simple phrases, in this case participants also obtained phonological acquisition stimuli in the form of 
the right intonation when saying the greetings and answering greetings, the question sentences من اسمك (what is your name) and the exclamation sentence مع السلامة (See you later).

The first participant, ANS represented a subject with a high school education background. This student is able to obtain eighteen vocabulary with five verbs classifications, three adjectives, five nouns, one conjunction and four simple phrases in the form of greetings and farewells. He is one of the people who get the most Arabic vocabulary because now he is in an environment based on Islam, of course this also affects the acquisition of language. As she said: "Even though I have never studied Arabic, at least I have heard, whether it's from a friend or lecturer. Anyway, a word that I understand a little familiar in my ears".

The second participant, AY represented a student with a high school education background. He was able to obtain eleven vocabulary with classifications of two verbs, three adjectives, five nouns, and three simple phrases in the form of greetings and thanksgiving. AY explained that the words he captured from cartoon films were in accordance with what he often heard so as to facilitate his understanding.

The third participant, AN represented students with a high school education background. $\mathrm{He}$ is also able to obtain eleven vocabulary with classifications of two verbs, seven nouns and two simple sentences in the form of greetings. As with other participants, AN explained that his Arabic vocabulary was limited to words he often heard.

The last participant, RZ represented a student with a vocational education background. $\mathrm{He}$ was able to obtain thirteen vocabulary with the classification of two verbs, two adjectives, seven nouns and two simple sentences in the form of greetings.

Based on the vocabulary mapping above, it can be concluded that the vocabulary obtained by many participants tends to real objects or objects accompanied by clear movements and instructions. Coordination between audio and visual stimuli presented in cartoon films facilitates the acquisition process because the Language Acquisition Device works actively to internalize each vocabulary that synergizes with the audience's understanding of the film [23]. Animated stimuli are more interesting and easier to remember learners than verbal verbal or written stimuli. This is as tested in a group of foreign language learners in Turkey [24]. Animated films, whether they provide subtitles or not, through story lines and characters can support simple vocabulary acquisition not only for children but also for teenagers and adults [25]. Ease of remembering the vocabulary of this cartoon film is supported by the affective domain so that language acquisition occurs naturally [26].

In addition, environmental factors also influence the acquisition of Arabic vocabulary for beginners. From this it is clear that the linguistic environment provides exposure to natural foreign language acquisition [27].

From the treatment applied, the results of the study indicate that nouns are more obtained than verbs. In fact they are also able to understand simple sentences such as greetings and thanksgiving, this is inseparable from their Muslim background in which greetings and thanksgiving are often used in everyday life.

The results of this study explain that Arabic-language cartoons can be a reference in acquiring vocabulary for beginners who did not have a history of learning Arabic at all. Evidenced by the research that has been done that with the use of one short duration cartoon movie screening, someone who is just learning Arabic can get some simple vocabulary and sentences.

\section{Conclusion}


In this study it was found that Arabic language acquirers with beginner categories were able to obtain some vocabulary from the short duration cartoon films they saw. In subjects who had never had Arabic before, showed the acquisition of nouns, verbs and simple phrases. As for adjectives, not all subjects can mention the acquisition of vocabulary. Thus it can be concluded that novice Arabic learners are helped by their vocabulary acquisition through short duration cartoon fim media. The findings of this study corroborate the empirical foundation that the cartoon format is not only effective in language learning but also in the context of Arabic, it has the potential to support the process of natural language acquisition. Considering that until today the use of media in Arabic classroom is not widely used [28], therefore Arabic teachers are recommended to use short animation movies to support learner's vocabulary acquisition.

Acknowledgements. This paper in conjuction with the 1st Annual International Conference on Language, Literature and Media (AICOLLIM)

\section{References}

[1] A.S. Hornby. Oxford Advanced Learners Dictionary. Oxford: Oxford University Press. 1995

[2] Nurhadi. Tata Bahasa Pendidikan: Landasan penyusunan buku pelajaran bahasa. Semarang: IKIP Semarang Press. 1995

[3] R. Schutz. Stephen Krashen's Theory of Second Language Acquisition (http://www.sk.com.br/sk-krash.html). 2006

[4] A. Chaer. Psikolinguistik Kajian Teoritik. Jakarta: Rineka Cipta. 2003

[5] H. Kridalaksana. Kamus Linguistik. Jakarta: Gramedia Pustaka Utama. 1983

[6] Roekhan. Menulis Kreatif: Dasar-Dasar dan Petunjuk Penerapannya. Malang: Yayasan Asih Asah Asuh Malang. 1991

[7] H. G. Tarigan. Pengajaran Kosakata. Bandung: Angkasa 2007

[8] S. U. S. Nababan. Psikolinguistik Suatu Pengantar. Jakarta: Gramedia Pustaka Utama. 1992.

[9] E. Ardianto \& L. K. Erdinaya. Komunikasi Massa Suatu Pengantar. Bandung: Remaja Rosdakarya. 2004

[10] Effendy, Onong Uchjana. (2000). Ilmu, Teori dan Filsafat Komunikasi. Bandung: Citra Aditya Bakti.

[11] Adinda \& Adjie. B1 $3 D$ Studio Max $9+C d$. Film Animasi 2D Berbasis $3 D$ MenggunakanTeknik Cell Shading Berjudul The Postman Story. Tugas Akhir. Surabaya: Stikom. 2011

[12] J. L. Jaana. Learning by viewing: cartoons as foreign language learning material for children-a case study. Journal of Educational Television vol. 20 no.2, 1994, pp.93-109.

[13] B. Abdurrahman Al-Wasa'il at Ta'limiyah: I'daduha wa Thuruqu Istikhdamuha. Beirut: Daru Ihya'. 1987

[14] L. A. Wahab "Pemerolehan kosakata bahasa Arab anak usia 2-7 tahun: Studi kasus beberapa anak di Konawe Selatan” Shautut Tarbiyah vol. 31 no.1, 2014, pp 48-64

[15] R. Makasau "Pembelajaran Bahasa Inggris Secara Insidental Melalui Film Kartun" Jurnal Jumpa, vol. 5 no. 2 2017, pp. 1-14.

[16] F. Kurniaty, L.Husna, \& Ernati "Teaching Vocabulary by Using Cartoon Movies For Junior High School Students" Abstract of Undergraduate, Faculty of Education, Bung Hatta University vol. 3 no. 5 2014, pp. 1-10

[17] M. S. B. Nasab, M. S. Beheshti \& S. F. P. Motlagh "Vocabulary Learning Promotion through English Subtitled Cartoons" Communication and Linguistics Studies vol. 3 no. 1, 2017, pp. 1-7. 
[18] P. A. Mukti Improving Student's Vocabulary Mastery using Cartoon Films. Thesis. Solo: Universitas Sebelas Maret. 2012

[19] D. Yüksel \& B. Tanriverdi "Effects of watching captioned movie clip on vocabulary development of EFL learners" The Turkish Online Journal of Educational Technology, vol. 8 no.2 2009, pp.48-54

2011

[20] L. J. Moelong, Metodologi Penelitian Kualitatif. Bandung: Remaja Rosdakarya.

[21] Sugiyono. Memahami Penelitian Kualitatif. Bandung: Alfabeta. 2005

[22] D. Abidat Al-Bahtsu al-Ilmi. Riyadh: Daru Asasiyah lin Nasyri wa atTauzi'.2004

[23] R.N. Indah \& Abdurrahman Psikolinguistik: konsep \& isu umum. Malang: UIN Press. 2008

[24] M.N. Kayaoglu, M. Naci; Akbas, R.D. \& Z. Ozturk "A small scale experimental study: using animations to learn vocabulary" TOJET: The Turkish Online Journal of Educational Technology vol. 10 no.2, 2011, pp.24-30

[25] A. Karakas \& A. Saricoban "The impact of watching subtitled animated cartoons on incidental vocabulary learning of ELT students" Teaching English with Technology, vol.12 no.4, 2012, pp.3-15

[26] Z.A.Aziz \& R. Sulicha "The use of cartoon films as audio-visual aids to teach English vocabulary" English Education Journal vol.7 no.2, 2016, pp. 141-154.

[27] B. Y.Cahyono \& R. N. Indah Second language research and pedagogy: Toward the development of English language teaching in Indonesia. Malang: UM Press. 2012

[28] I. M. M.. Yasim, M. A. Lubis, Z. A. M.. Noor, M. Y. "The use of teaching aids in the teaching and learning of Arabic Language vocabulary" Creative Education vol. 7 no. 1. 2016, pp.443-448. 